\title{
Natalizumab in acute ischemic stroke (ACTION II)
}

\author{
A randomized, placebo-controlled trial
}

Mitchell S.V. Elkind, MD, Roland Veltkamp, MD, Joan Montaner, MD, PhD, S. Claiborne Johnston, MD, PhD, Aneesh B. Singhal, MD, Kyra Becker, MD, Maarten G. Lansberg, MD, PhD, Weihua Tang, PhD,

Rachna Kasliwal, MPH, and Jacob Elkins, MD

Neurology ${ }^{\circledR}$ 2020;95:e1091-e1104. doi:10.1212/WNL.0000000000010038

\section{Abstract}

\section{Objective}

We evaluated the effect of 2 doses of natalizumab on functional outcomes in patients with acute ischemic stroke (AIS).

\section{Methods}

In this double-blind phase $2 \mathrm{~b}$ trial, patients with AIS aged $18-80$ years with NIH Stroke Scale scores of 5-23 from 53 US and European sites were randomized 1:1:1 to receive a single dose of 300 or $600 \mathrm{mg}$ IV natalizumab or placebo, with randomization stratified by treatment window ( $\leq 9$ or $>9$ to $\leq 24$ hours from patient's last known normal state). The primary endpoint was a composite measure of excellent outcome (modified Rankin Scale score $\leq 1$ and Barthel Index score $\geq 95$ ) at day 90 assessed in all patients receiving a full dose. Sample size was estimated from a Bayesian model; $p$ values were not used for hypothesis testing.

\section{Results}

An excellent outcome was less likely with natalizumab than with placebo (natalizumab 300 or $600 \mathrm{mg}$ odds ratio $0.60 ; 95 \%$ confidence interval $0.39-0.93$ ). There was no effect modification by time to treatment or use of thrombolysis/thrombectomy. For natalizumab $300 \mathrm{mg}, 600 \mathrm{mg}$, or placebo, there were no differences in incidence of adverse events (90.0\%, 92.1\%, and 92.3\%, respectively), serious adverse events $(25.6 \%, 32.6 \%$, and $20.9 \%$, respectively), or deaths (6.7\%, $4.5 \%$, and $5.5 \%$, respectively).

\section{Conclusions}

Natalizumab administered $\leq 24$ hours after AIS did not improve patient outcomes.

\section{ClinicalTrials.gov identifier NCT02730455}

\section{Classification of evidence}

This study provides Class I evidence that for patients with AIS, an excellent outcome was less likely in patients treated with natalizumab than with placebo.

\section{Correspondence} Dr. Elkind mse13@columbia.edu

\section{MORE ONLINE}

$\rightarrow$ Class of Evidence

Criteria for rating therapeutic and diagnostic studies

NPub.org/coe

From Columbia University (M.S.V.E.), New York, NY; Imperial College London (R.V.), UK; Alfried-Krupp Krankenhaus (R.V.), Essen, Germany; Vall d'Hebron Research Institute (VHIR) (J.M.), Barcelona; Institute of Biomedicine of Seville (IBiS) Stroke Programme (J.M.), Spain; University of Texas (S.C.J.), Austin; Massachusetts General Hospital (A.B.S.), Boston; University of Washington (K.B.), Seattle; Stanford University Medical Center (M.G.L.), Stanford Stroke Center, CA; and Biogen (W.T., R.K., J.E.), Cambridge, MA.

Go to Neurology.org/N for full disclosures. Funding information and disclosures deemed relevant by the authors, if any, are provided at the end of the article.

ACTION II Investigators group members are listed in appendix 2 at the end of the article.

This Null Hypothesis article is published as part of a collaborative effort between Neurology ${ }^{\circledR}$ and CBMRT. 


\section{Glossary}

ACTION II = Safety and Efficacy of Intravenous Natalizumab in Acute Ischemic Stroke; AE = adverse event; AIS = acute ischemic stroke; BI = Barthel Index; CI = confidence interval; DWI = diffusion-weighted imaging; GEE = generalized estimating equation; $\mathbf{I Q R}=$ interquartile range; $\mathbf{L K N}$ = last known normal; $\mathbf{m I T T}=$ modified intent-to-treat; $\mathbf{M o C A}=$ Montreal Cognitive Assessment; $\mathbf{m R S}=$ modified Rankin Scale; MS = multiple sclerosis; NIHSS = NIH Stroke Scale; OR = odds ratio; SAE = serious adverse event; SIS-16 = Stroke Impact Scale-16; tPA = tissue plasminogen activator; VLA-4 = very late antigen-4.

Innate and adaptive immune responses after ischemic brain injury are thought to contribute to brain injury and poor functional outcomes. ${ }^{1}$ Leukocyte infiltration after ischemic stroke mediates and exacerbates immune-mediated injury. ${ }^{2-4}$ In animal models of ischemic stroke, postischemic inflammation leads to larger infarcts and worse functional outcomes. ${ }^{2-4}$ Monoclonal antibodies against the CD49d receptor target the $a$ chain of the adhesion molecule very late antigen-4 (VLA-4) and reduce leukocyte migration into the $\mathrm{CNS}^{4-8}$ In preclinical studies, ${ }^{4-8}$ including a multicenter preclinical randomized trial, ${ }^{8}$ these antibodies have been shown to decrease leukocyte infiltration, reduce infarct volume, and improve functional outcomes in some, though not all, mouse models of ischemic stroke.

Natalizumab is a monoclonal antibody targeting $\alpha-4$ integrin within VLA-4, leading to reduced transmigration of leukocytes across the vascular endothelium. ${ }^{9,10}$ Natalizumab is approved for the treatment of multiple sclerosis (MS) and Crohn's disease ${ }^{11}$ and is highly effective at reducing inflammatory lesions within the CNS of patients with MS. ${ }^{10,12}$ Several putative mediators of postischemic inflammation in experimental stroke models, including $\gamma \delta$ $\mathrm{T}$ cells, T-effector cells, and macrophages, express VLA$4^{6,13,14}$

In a prior proof-of-concept phase 2 clinical trial testing the effect of a single 300-mg IV infusion of natalizumab among 161 patients with ischemic stroke treated within 9 hours of symptom onset, natalizumab did not affect infarct volume growth (the primary study endpoint) but did result in improvement on several prespecified secondary and tertiary endpoints of functional outcome at 30 and 90 days, compared with placebo. ${ }^{15}$ Exposure-response analyses of this trial suggested that higher concentrations of natalizumab were associated with a higher likelihood of a good functional outcome, indicating that further dose exploration may be warranted.

The primary goal of the present trial was to further test the hypothesis that natalizumab is associated with improved patient functional outcomes when administered after acute ischemic stroke (AIS). The study also aimed to evaluate the efficacy at 2 different doses of a single IV infusion of natalizumab and to assess benefit up to 24 hours after stroke symptom onset.

\section{Methods}

\section{Standard protocol approvals, registrations, and patient consents}

Patients from 53 clinical sites in Germany (19 sites), the United States (18 sites), Spain (12 sites), and the United Kingdom (4 sites) were enrolled. Prior to randomization, all patients received standard of care for stroke. Any treatments provided by the local physician, including IV recombinant tissue plasminogen activator (tPA; alteplase) and mechanical thrombectomy, were performed before inclusion in the trial. The study was performed in accordance with applicable International Conference on Harmonisation of Technical Requirements for Pharmaceuticals for Human Use and Good Clinical Practice guidelines. Ethics approval was granted by each center's local or national independent ethics committee. The study is registered at ClinicalTrials.gov (NCT02730455). Before undergoing any study procedures, patients provided written informed consent.

\section{Study design}

The ACTION II study was a multicenter, double-blind, doseranging, placebo-controlled, randomized phase 2 study evaluating the safety and efficacy over 90 days of natalizumab administered as a single IV infusion at 2 different doses (300 and $600 \mathrm{mg}$ ) in patients with AIS.

\section{Patient selection}

Eligible patients were 18-80 years old (inclusive) at the time of enrollment, had a clinical diagnosis of supratentorial AIS defined by last known normal (LKN) $\leq 24$ hours prior to study treatment initiation, and an NIH Stroke Scale (NIHSS) ${ }^{16}$ score of 5-23 points (inclusive) at screening for patients initiating treatment $\leq 9$ hours from $\mathrm{LKN}$ or $5-15$ points (inclusive) for patients initiating treatment $>9$ to $\leq 24$ hours from LKN. Prior to the stroke, included patients were able to perform basic activities of daily living without assistance. MRI scans were not required for inclusion, but for those who underwent cranial MRI, there had to be at least one acute infarct with a diameter of $\geq 2 \mathrm{~cm}$ on baseline brain diffusion-weighted imaging (DWI). For patients who underwent thrombolysis or mechanical thrombectomy, the NIHSS score had to be reconfirmed within 60 minutes prior to randomization. Patients of childbearing potential were required to be willing and able to practice contraception during the study.

Exclusion criteria included lacunar or isolated brainstem or cerebellar stroke based on clinical assessment and available acute imaging studies performed under the standard of care; 
the presence of acute intracranial hemorrhage on acute brain CT or MRI (with petechial hemorrhages $\leq 1 \mathrm{~cm}$ not considered exclusionary); severe stroke defined by imaging criteria (an Alberta Stroke Program Early CT score of 0-4 based on head CT or acute infarct volume on MRI DWI $\geq 70 \mathrm{~mL}$ ); seizure at the onset of stroke; known history of immunocompromised status, history of progressive multifocal leukoencephalopathy, prior treatment with natalizumab, or participation in any other study that involved treatment with an investigational drug within 6 months prior to enrollment; hypersensitivity reaction to $\mathrm{PA}$ administered for the stroke; a known history of testing positive for HIV or of active viral hepatitis B or C; signs of active herpes simplex type 1 or 2 or varicella within 4 weeks prior to randomization; and signs and symptoms of active or acute infection. Patients who were nursing or pregnant and patients with significant medical disorders, neurologic disorders (other than stroke), or psychiatric disorders or a known history of substance abuse that might preclude safe participation or render the patient unable to comply with study requirements were also excluded.

All candidates were required to provide signed and dated informed consent. In the event that a candidate was not able to give consent, informed consent could be provided either by a representative of the candidate or through another process that was in compliance with local institutional review board and ethics committee guidelines.

\section{Randomization and masking}

At baseline, eligible patients were randomized 1:1:1 to receive a single dose of $300 \mathrm{mg}$ IV natalizumab, $600 \mathrm{mg}$ IV natalizumab, or placebo (figure 1A). Patients were randomized and registered by an Interactive Voice/Web Response System (IXRS; Almac, Craigavon, UK), which provided a computergenerated allocation sequence. Two separate randomization schemes were used for patients in the 2 treatment windows ( $\leq 9$ hours or $>9$ to $\leq 24$ hours from LKN): for patients in the $\leq 9$ hours group, randomization was stratified by baseline NIHSS score (5-15 vs 16-23), tPA use, and region; for patients in the $>9$ to $\leq 24$ hours group, randomization was stratified by whether patients also had tPA use and by region. Patients, investigators, and study staff were blinded to patient treatment assignments, and natalizumab and placebo were provided in color-matched vials.

\section{Study objectives and measures}

The NIHSS score, used to assess the clinical severity of acute cerebral infarction, was collected at screening and at $24 \pm 6$ hours, 5 days, $30 \pm 5$ days, and $90 \pm 5$ days. This is a 15-item questionnaire, with 0 as normal and a maximum possible score of 42 for all items; it takes 5-10 minutes to administer. ${ }^{16}$ Additional functional outcomes, including modified Rankin Scale (mRS) and the Barthel Index (BI), were collected at 5 days, $30 \pm 5$ days, and $90 \pm 5$ days. Blood samples for pharmacokinetic and pharmacodynamic testing were collected at screening, within 1 hour of natalizumab infusion, and at $12 \pm 3$ hours, $24 \pm 6$ hours, 5 days, $30 \pm 5$ days, and $90 \pm 5$ days.
Safety events were reported throughout the study. For patients unable to return to the study center at day 30 or 90 , efficacy and safety outcomes could be collected remotely where this was allowed by local regulations.

The primary endpoint of the study was the composite global measure of functional disability based on a score of 0 or 1 on the $\mathrm{mRS}$ and a score of $\geq 95$ on the BI at day 90 . These mRS and BI thresholds were similar to those used in prior studies of acute stroke therapies, including those demonstrating the benefit of IV tPA in AIS. ${ }^{17,18}$ These outcomes were also chosen based on the evidence of efficacy of natalizumab in improving outcomes on these scales in the original phase 2 trial of natalizumab. ${ }^{15}$ The mRS measures independence with regard to specific tasks before and after stroke. ${ }^{17}$ The scale consists of 7 grades from 0 to 6 , with 0 representing no symptoms and 6 representing death. The BI consists of 10 items that measure a person's daily functioning, specifically the activities of daily living and mobility. Each item is measured on a 10-point scale, adding up to a maximum total score of 100, with higher scores indicating higher independence of the participant in performing these tasks. All study personnel responsible for administering these primary outcome tests were duly certified.

The following secondary efficacy outcome measures were chosen to explore the impact of natalizumab on outcomes: (1) mRS score, (2) BI score, (3) Stroke Impact Scale-16 (SIS-16) score, (4) Montreal Cognitive Assessment (MoCA) score, and (5) NIHSS score. The SIS-16 is an instrument that measures 16 physical capabilities rated on a scale of 1 (could not do at all) to 5 (not difficult at all) and takes less than 5 minutes to administer. ${ }^{19}$ The MoCA is a global cognitive screening test that screens 8 psychometric domains and takes approximately 10 minutes to administer. ${ }^{20}$ Safety endpoints were assessed as incidence of adverse events (AEs) and serious AEs (SAEs). All AEs and SAEs were adjudicated as being related or not related to the study treatment.

Additional prespecified exploratory endpoints examined the effects of treatment on other clinical outcomes using the following standard measures: the Functional Independence Measure, the Symbol Digit Modalities Test, the Fatigue Severity Scale, the Beck Depression Inventory 2, and the EuroQoL 5-dimensions/3 levels questionnaire. Secondary and exploratory efficacy outcomes were evaluated at day 90 , with additional analyses at days 5 and 30. Exploratory pharmacokinetics and pharmacodynamics of natalizumab were assessed as the serum concentration of natalizumab (as determined using a validated ELISA), $a 4$ integrin saturation, and CD49d expression.

\section{Statistical analysis}

The sample size calculations assumed a true odds ratio (OR) of 1.8 as observed in the pooled secondary endpoint analyses of the ACTION trial. The sample size of 270 provided $88 \%$ probability to find an $\mathrm{OR} \geq 1.3$ for the primary comparison of 
Figure 1 Safety and Efficacy of Intravenous Natalizumab in Acute Ischemic Stroke (ACTION II) study design and patient disposition

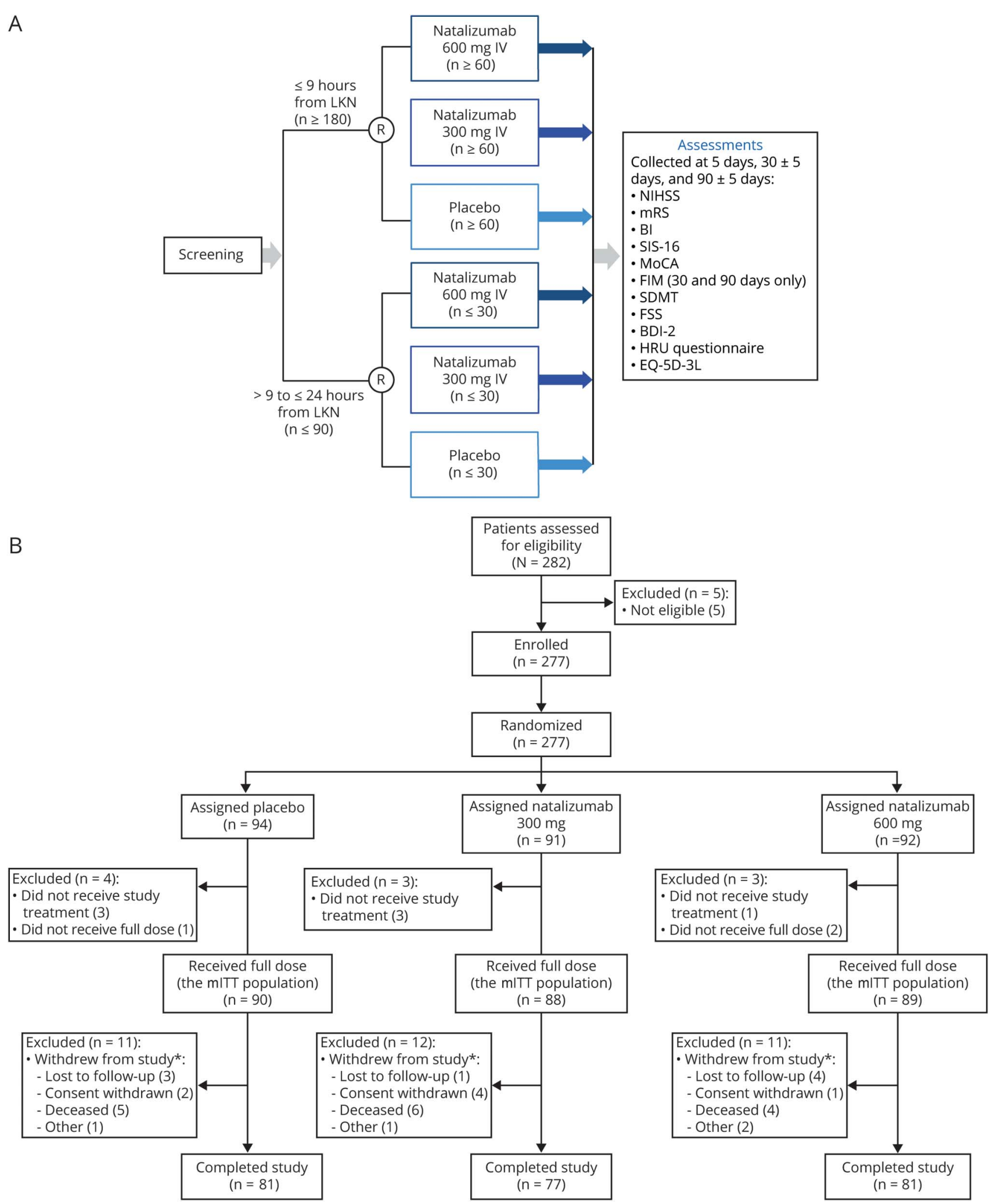

(A) ACTION II study design and (B) patient disposition. *Number of patients withdrawn includes some patients who withdrew prior to receiving a full dose of study treatment. BDI-2 = Beck Depression Inventory 2; BI = Barthel Index; EQ-5D-3L = EuroQoL 5 dimensions/3 levels; FIM = Functional Independence Measure; FSS = Fatigue Severity Scale; HRU = healthcare resource utilization; LKN = last known normal; mITT = modified intent-to-treat; MoCA = Montreal Cognitive Assessment; mRS = modified Rankin Scale; NIHSS = NIH Stroke Scale; R = randomization; SDMT = Symbol Digit Modalities Test; SIS-16 = Stroke Impact Scale-16. 
natalizumab (dose groups combined) vs placebo on the global composite measure at day 90 . An OR $\geq 1.3$ on the global outcome measure was considered to be clinically meaningful based on the effect of TPA in the 3- to 4.5-hour time window.

As prespecified in the study protocol, all efficacy analyses were performed for the modified intent-to-treat (mITT) population, defined as all patients who were randomized and received the entire infusion of study treatment. The safety population was defined as patients who had received any study treatment, including cases of complete or incomplete infusion. Safety was assessed and the incidence of AEs and SAEs was analyzed using descriptive statistics.

The primary global estimate for overall improvement across the $\mathrm{mRS}$ and $\mathrm{BI}$ was calculated using generalized estimating equation (GEE) models with the logit link function to estimate the OR and $95 \%$ confidence interval (CI), as in prior studies. ${ }^{21}$ The 2 components were the within-patient repeated measures in the GEE model. Treatment was included in statistical modelling as a categorical variable with 3 levels (300 mg, $600 \mathrm{mg}$, and placebo). Additional covariates included in the models were baseline NIHSS category (score 5-15 or 16-23); tPA use (yes/no); thrombectomy (yes/no); age ( $<60,60-69$, or $70-80$ years); treatment window ( $\leq 9$ or $>9$ to $\leq 24$ hours from LKN); and region (United Kingdom/ Germany, Spain, or United States). For missing day $90 \mathrm{mRS}$ and BI scores, multiple imputation methods (with 50 replications) were utilized. Patients who died were not treated as having missing data. For mRS, a score of 6 was recorded for any deaths.

To determine the treatment window in the primary analysis population, the interaction between treatment and treatment window was first tested in a logistic regression model that included these covariates and a 2-way interaction term. The analysis plan prespecified that if the $p$ value of the interaction term between treatment and treatment window was $\geq 0.3$ for the combined active-dose groups vs placebo, the primary analysis population would include patients in both treatment windows, and a main effect-only GEE model with the same covariates as described above would be the basis of the primary analysis. Otherwise, if the $p$ value of the interaction was $<0.3$, the primary analysis population would include patients in the $\leq 9$ hours from LKN window only. A separate analysis for patients with treatment window $>9$ and $\leq 24$ hours from LKN was also to be performed.

Depending on the primary treatment window based on the interaction test, the global OR in the primary analysis model of active ( 2 doses combined) vs placebo treatment was derived from the GEE model. All calculated $p$ values were 2 -sided. Because the study sample size was estimated based on a Bayesian model with a prior probability from the previously completed ACTION trial, ${ }^{15} p$ values were not used as the basis for hypothesis testing and thus are not reported for efficacy endpoints.
Additional prespecified analyses were performed combining the data from the primary outcome measure, mRS, and BI from this trial with the data from the prior ACTION trial to determine if there was evidence of benefit.

\section{Data availability}

The datasets generated or analyzed during the current study are not publicly available. The authors and company are fully supportive of allowing independent assessment and verification of these results. Requests for deidentified data should be made via the established company data-sharing policies and processes as detailed on the website clinicalresearch.biogen. $\mathrm{com} /$.

\section{Classification of evidence}

This study provides Class I evidence on whether patients with AIS are more likely to experience an excellent outcome with natalizumab than with placebo.

\section{Results}

\section{Patient disposition}

Between July 18, 2016, and November 20, 2017, 277 patients were randomized across 53 study sites in the United States and Europe (figure 1). Seven patients did not receive any study treatment, and 3 did not receive a full dose of study treatment. The remaining 267 patients (88 natalizumab $300 \mathrm{mg}, 89$ natalizumab $600 \mathrm{mg}$, and 90 placebo) received a full dose of study treatment and were included in the mITT population, as per study protocol.

\section{Baseline characteristics}

At baseline, patients had a mean (SD) age of 66.3 (10.5) years and had a median (interquartile range $[\mathrm{IQR}]$ ) NIHSS score of 9 (6-14) (table 1). The median (IQR) time from symptom onset (i.e., LKN) to treatment was 8.3 (6.3-14.0) hours, with a median of 7.3 hours in the $\leq 9$ hours category $(\mathrm{n}=176)$ and 16.7 hours in the $>9$ to $\leq 24$ hours category ( $\mathrm{n}$ $=89)$. In the mITT population, 168 patients $(63 \%)$ were administered tPA and 113 patients (42\%) underwent thrombectomy prior to study treatment (table 1). A total of 212 patients (79\%) received IV tPA and/or underwent thrombectomy, while 76 patients (28\%) received both tPA and thrombectomy.

Overall, baseline demographics, stroke severity (baseline NIHSS score), and frequency of thrombolytic and thrombectomy use were well balanced among the 3 treatment groups in the mITT population (table 1).

\section{Efficacy outcomes}

In the analysis of the primary endpoint, no significant interaction effect was observed between study treatment and treatment window $(p=0.570)$, so the analysis population included both treatment windows. The 2-component (mRS and $\mathrm{BI}$ ) composite excellent outcome was less likely among those who received natalizumab than those who received 
Table 1 Baseline demographics and disease characteristics of the modified intent-to-treat population

\begin{tabular}{|c|c|c|c|c|c|}
\hline & Placebo $(n=90)$ & $\begin{array}{l}\text { Natalizumab } \\
300 \mathrm{mg}(\mathrm{n}=88)\end{array}$ & $\begin{array}{l}\text { Natalizumab } \\
600 \mathrm{mg}(\mathrm{n}=89)\end{array}$ & $\begin{array}{l}\text { Natalizumab } \\
300 \mathrm{mg}+600 \mathrm{mg}(\mathrm{n}=177)\end{array}$ & Total $(n=267)$ \\
\hline \multicolumn{6}{|l|}{ Age, y } \\
\hline Median & $68.5(61,76)$ & $69(60.5,75)$ & $68(57,74)$ & $68(59,75)$ & $68(59,75)$ \\
\hline$<60$ & $20(22)$ & $20(23)$ & $29(33)$ & $49(28)$ & $69(26)$ \\
\hline $60-69$ & $27(30)$ & $28(32)$ & $21(24)$ & $49(28)$ & $76(28)$ \\
\hline $70-80$ & $43(48)$ & $40(45)$ & $39(44)$ & $79(45)$ & $122(46)$ \\
\hline \multicolumn{6}{|l|}{ Sex } \\
\hline Male & $63(70)$ & $53(60)$ & $54(61)$ & $107(60)$ & $170(64)$ \\
\hline Female & $27(30)$ & $35(40)$ & $35(39)$ & $70(40)$ & $97(36)$ \\
\hline Weight, $\mathbf{k g}^{\mathrm{a}}$ & $84(78,95)$ & $80(70,97)$ & $78.5(65.4,90)$ & $80(70,92)$ & $80(72,93.2)$ \\
\hline BMI, median & $27.9(25.5,31.1)$ & $27.5(24.8,33.4)$ & $27.2(23.6,31.2)$ & $27.4(24.4,31.6)$ & $27.7(24.9,31.6)$ \\
\hline \multicolumn{6}{|l|}{ Location of stroke } \\
\hline Left hemisphere & $46(51)$ & $40(45)$ & $43(49)$ & $83(47)$ & $129(48)$ \\
\hline Right hemisphere & $42(47)$ & $48(55)$ & $44(50)$ & $92(52)$ & $134(50)$ \\
\hline Both & $2(2)$ & 0 & $1(1)$ & $1(<1)$ & $3(1)$ \\
\hline Received tPA or thrombectomy & $73(81)$ & $68(77)$ & $71(80)$ & $139(79)$ & $212(79)$ \\
\hline Received tPA prior to study drug & $56(62)$ & $56(64)$ & $56(63)$ & $112(63)$ & $168(63)$ \\
\hline Thrombectomy & $38(42)$ & $36(41)$ & $39(44)$ & $75(42)$ & $113(42)$ \\
\hline \multicolumn{6}{|l|}{ Baseline NIHSS score $^{c}$} \\
\hline Median & $9.5(6,13)$ & $9(6,13.5)$ & $10(6,14)$ & $9(6,14)$ & $9(6,14)$ \\
\hline $5-15$ & $77(87)$ & $74(84)$ & $75(84)$ & $149(84)$ & $226(85)$ \\
\hline $16-23$ & $12(13)$ & $14(16)$ & $14(16)$ & $28(16)$ & $40(15)$ \\
\hline History of diabetes & $28(31)$ & $25(28)$ & $15(17)$ & $40(23)$ & $68(25)$ \\
\hline Glucose at entry, $\mathrm{mmol} / \mathrm{L}^{\mathrm{d}}$ & $6.5(5.5,7.8)$ & $6.7(5.7,8.2)$ & $6.5(5.6,7.4)$ & $6.6(5.7,7.8)$ & $6.5(5.6,7.8)$ \\
\hline \multicolumn{6}{|c|}{$\begin{array}{l}\text { Abbreviations: BMI = body mass index; NIHSS = NIH Stroke Scale; tPA = tissue plasminogen activator. } \\
\text { Values are } \mathrm{n}(\%) \text { or median (Q1, Q3). } \\
\text { a Data were not available for } 1 \text { natalizumab } 300 \mathrm{mg} \text { patient. } \\
\text { b Data were not available for } 1 \text { natalizumab } 600 \mathrm{mg} \text { patient. } \\
\text { c Data were not available for } 1 \text { placebo patient. } \\
\text { d Data were not available for } 2 \text { natalizumab } 300 \mathrm{mg} \text { patients and } 6 \text { natalizumab } 600 \mathrm{mg} \text { patients. }\end{array}$} \\
\hline
\end{tabular}

placebo (OR [95\% CI] of 0.60 [0.39-0.93] for natalizumab $300+600 \mathrm{mg}$ groups combined vs placebo). Results were similar for the individual treatment groups: OR $(95 \% \mathrm{CI}) 0.64$ (0.38-1.07) for natalizumab $300 \mathrm{mg}$ vs placebo and 0.57 (0.34-0.95) for natalizumab $600 \mathrm{mg}$ vs placebo (table 2).

In a secondary analysis, similar results were observed using a global composite good outcome (i.e., mRS score of $0-2$ and BI score $\geq 85$ ), with an OR (95\% CI) of $0.53(0.32-0.87)$ for natalizumab $300 \mathrm{mg}+600 \mathrm{mg}$ vs placebo. In subgroup analyses of the global composite excellent outcome by treatment window ( $\leq 9$ hours vs $>9$ to $\leq 24$ hours), tPA use, or thrombectomy, results were similar to those in the overall mITT population (figure $2 \mathrm{~A}$ ).
For secondary outcomes evaluating effects on individual functional outcome measures, there was no benefit for excellent outcomes on either the mRS or the BI considered independently (table 2). Subgroup analyses showed no notable differences based on treatment window, tPA use, or thrombectomy (figure 2, B and C). In an analysis of the shift of functional outcomes scores, taking account of the full spectrum of scores, there was no evidence of a beneficial effect of natalizumab (with a shift OR of 0.65 [95\% CI 0.38-1.11] for both natalizumab $300 \mathrm{mg}$ vs placebo and natalizumab $600 \mathrm{mg}$ vs placebo) (figure $2 \mathrm{D}$ ).

The percentages of patients with MoCA scores $\geq 22, \geq 24$, or $\geq 26$ were generally similar in the placebo and natalizumab 
Table 2 Efficacy outcomes of natalizumab- and placebo-treated patients in the modified intent-to-treat population at 90 days

\begin{tabular}{|c|c|c|c|c|c|c|c|}
\hline & $\begin{array}{l}\text { Placebo, n/N } \\
\text { (\%) }\end{array}$ & $\begin{array}{l}\text { Natalizumab } \\
300 \mathrm{mg}, \mathrm{n} / \mathrm{N} \\
(\%)\end{array}$ & $\begin{array}{l}\text { Natalizumab } \\
300 \text { mg vs } \\
\text { placebo, OR } \\
(95 \% \mathrm{Cl})\end{array}$ & $\begin{array}{l}\text { Natalizumab } \\
600 \mathrm{mg}, \mathrm{n} / \mathrm{N} \\
(\%)\end{array}$ & $\begin{array}{l}\text { Natalizumab } \\
600 \mathrm{mg} \text { vs } \\
\text { placebo, OR } \\
(95 \% \mathrm{Cl})\end{array}$ & $\begin{array}{l}\text { Natalizumab } \\
300 \mathrm{mg}+ \\
600 \mathrm{mg}, \mathrm{n} / \mathrm{N} \\
(\%)\end{array}$ & $\begin{array}{l}\text { Natalizumab } \\
300 \mathrm{mg}+600 \mathrm{mg} \text { vs } \\
\text { placebo, OR (95\% } \\
\mathrm{CI})\end{array}$ \\
\hline \multicolumn{8}{|c|}{ Primary endpoint } \\
\hline $\begin{array}{l}\text { Global } \\
\text { composite } \\
\text { excellent } \\
\text { outcome }\end{array}$ & - & - & $0.64(0.38-1.07)$ & - & $0.57(0.34-0.95)$ & - & $0.60(0.39-0.93)$ \\
\hline $\begin{array}{l}\text { Global } \\
\text { composite } \\
\text { good } \\
\text { outcome } \\
\text { (sensitivity) }\end{array}$ & - & - & $0.52(0.29-0.96)$ & - & $0.53(0.30-0.94)$ & - & $0.53(0.32-0.87)$ \\
\hline
\end{tabular}

\begin{tabular}{|c|c|c|c|c|c|c|c|}
\hline \multicolumn{8}{|c|}{ Secondary endpoints } \\
\hline \multicolumn{8}{|l|}{ mRS score } \\
\hline 0 or 1 & $35 / 86(41)$ & $24 / 83(29)$ & $0.67(0.35-1.28)$ & $21 / 82(26)$ & $0.54(0.28-1.06)$ & 45/165 (27) & $0.60(0.34,1.06)$ \\
\hline 0,1, or 2 & $60 / 86(70)$ & $43 / 83(52)$ & $0.49(0.25-0.96)$ & $43 / 82(52)$ & $0.48(0.25-0.94)$ & $86 / 165(52)$ & $0.49(0.27-0.87)$ \\
\hline \multicolumn{8}{|l|}{ BI score } \\
\hline$\geq 95$ & $58 / 86(67)$ & 44/81 (54) & $0.56(0.29-1.08)$ & $44 / 81(54)$ & $0.54(0.28-1.04)$ & $88 / 162(54)$ & $0.55(0.31,0.98)$ \\
\hline$\geq 85$ & $66 / 86(77)$ & $53 / 81(65)$ & $0.55(0.27-1.13)$ & $54 / 81(67)$ & $0.58(0.28-1.19)$ & 107/162 (66) & $0.56(0.30-1.06)$ \\
\hline \multicolumn{8}{|l|}{ MoCA score } \\
\hline$\geq 22$ & $51 / 90(57)$ & $52 / 88(59)$ & $1.08(0.55-2.13)$ & $53 / 89(60)$ & $1.06(0.53-2.10)$ & 105/177 (59) & $1.07(0.59-1.93)$ \\
\hline$\geq 24$ & $43 / 90(48)$ & $41 / 88(47)$ & $0.89(0.45-1.76)$ & $40 / 89(45)$ & $0.76(0.38-1.51)$ & $81 / 177(46)$ & $0.82(0.46-1.48)$ \\
\hline$\geq 26$ & $31 / 90(34)$ & $26 / 88(30)$ & $0.72(0.35-1.45)$ & $30 / 89$ (34) & $0.81(0.40-1.64)$ & 56/177 (32) & $0.76(0.42-1.40)$ \\
\hline $\begin{array}{c}\text { SIS-16 score } \geq \\
\text { median }^{\mathrm{a}}\end{array}$ & $65 / 90(72)$ & $52 / 88(59)$ & $0.53(0.27-1.03)$ & $52 / 89(58)$ & $0.49(0.25-0.95)$ & 104/177 (59) & $0.51(0.28-0.92)$ \\
\hline $\begin{array}{l}\text { NIHSS score } \\
\text { of } 0 \text { or } 1\end{array}$ & $42 / 77(55)$ & $30 / 76$ (39) & $0.61(0.31-1.18)$ & 24/71 (34) & $0.53(0.27-1.06)$ & 54/147 (37) & $0.57(0.32-1.01)$ \\
\hline
\end{tabular}

Abbreviations: $\mathrm{BI}$ = Barthel Index; $\mathrm{Cl}$ = confidence interval; MoCA = Montreal Cognitive Assessment; mRS = modified Rankin Scale; NIHSS = NIH Stroke Scale; OR = odds ratio; SIS-16 = Stroke Impact Scale-16.

If a patient is known to be dead on or before a specific postbaseline visit, the missing mRS or BI scores at that specific visit and all remaining visits are set to the worst possible outcome; otherwise, multiple imputation methods are applied for missing mRS and BI scores.

a Median is calculated across all visits in all treatment arms.

treatment groups (table 2). A greater proportion of patients in the placebo group had SIS-16 scores at or above median and NIHSS scores of 0 or 1 compared with the natalizumab groups; ORs were similar to those observed for $\mathrm{mRS}$ and BI scores (table 2).

When the data from the ACTION and ACTION II trials were pooled, as prespecified in the statistical analysis plan, there was no evidence of natalizumab having a beneficial effect (OR of a composite excellent outcome [95\% CI] 0.85 [0.58-1.24] for natalizumab 300 or $600 \mathrm{mg}$ vs placebo). Among the patients assigned to natalizumab (either dose) in the 2 trials, the proportion of patients with an mRS score of 0 or 1 was $27 \%$ ( 63 of 237), compared with $31 \%$ ( 51 of 164 ) among the patients assigned placebo (OR [95\% CI] $0.76[0.47-1.23])$. A BI score $\geq 95$ was achieved in $53 \%$
(119 of 226) of patients assigned to natalizumab vs 54\% (83 of 154 ) of patients assigned to placebo (OR [95\% CI] 0.91 [0.57-1.45]).

No evidence of a benefit was observed on any of the exploratory efficacy endpoints (table 3 ). In the pharmacokinetics analysis, the mean peak serum natalizumab concentration was twice as high in the $600 \mathrm{mg}$ natalizumab group as in the $300 \mathrm{mg}$ group (226.81 vs $109.95 \mathrm{mg} / \mathrm{L}$ ) (table 3). Mean serum natalizumab concentrations over time are shown in figure 3A. Exposure of natalizumab in patients treated with the $600 \mathrm{mg}$ dose was also approximately double that in the patients treated with $300 \mathrm{mg}$ natalizumab (table 3). In pharmacodynamic analyses, median a4 integrin saturation increased from $3.0 \%$ to $3.5 \%$ at baseline to $97.9 \%$ in the natalizumab $300 \mathrm{mg}$ group and $98.1 \%$ in the natalizumab 
A

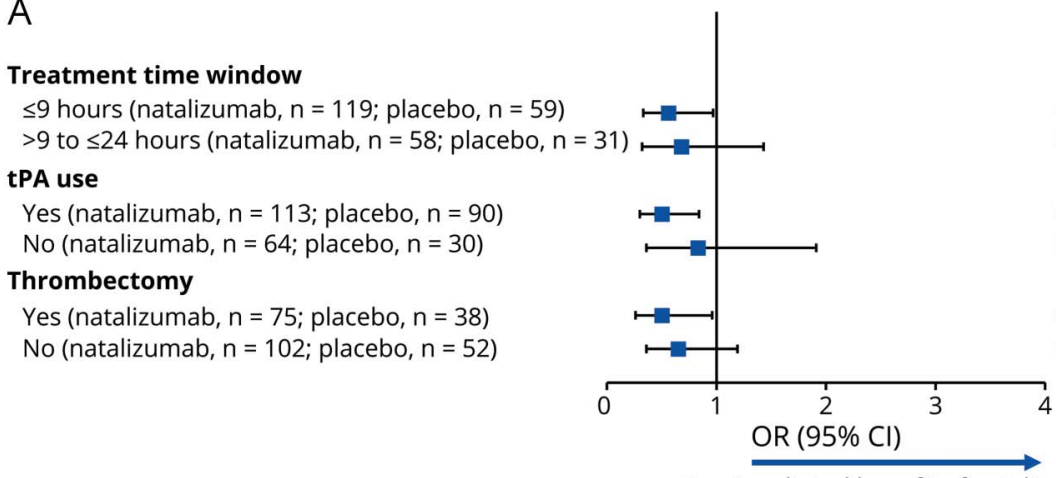

OR $(95 \% \mathrm{Cl})$

$0.56(0.33-0.97)$

$0.68(0.32-1.43)$

$0.50(0.30-0.84)$

$0.83(0.36-1.91)$

$0.50(0.26-0.96)$

$0.65(0.36-1.19)$

Greater clinical benefit of natalizumab

B

Treatment time window

$\leq 9$ hours

$>9$ to $\leq 24$ hours

tPA use

Yes

No

Thrombectomy

Yes

No

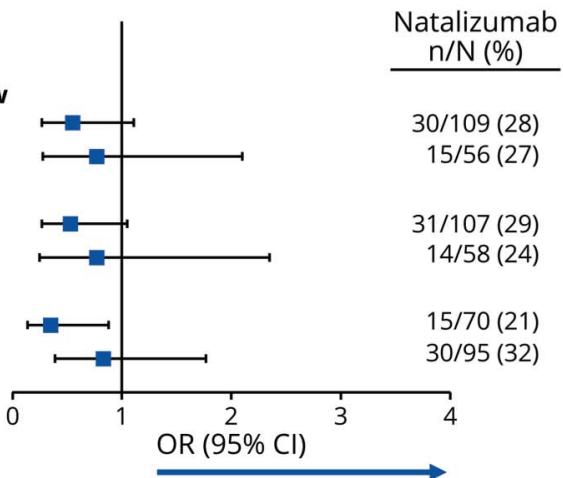

Natalizumab Placebo

$\mathrm{n} / \mathrm{N}(\%) \quad \mathrm{OR}(95 \% \mathrm{Cl})$

Greater clinical benefit of natalizumab

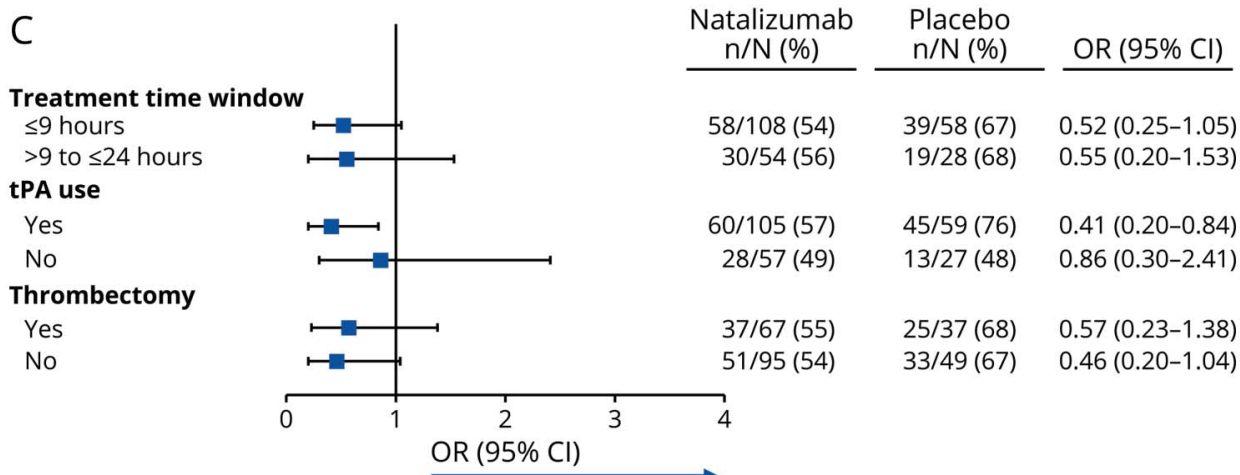

Greater clinical benefit of natalizumab

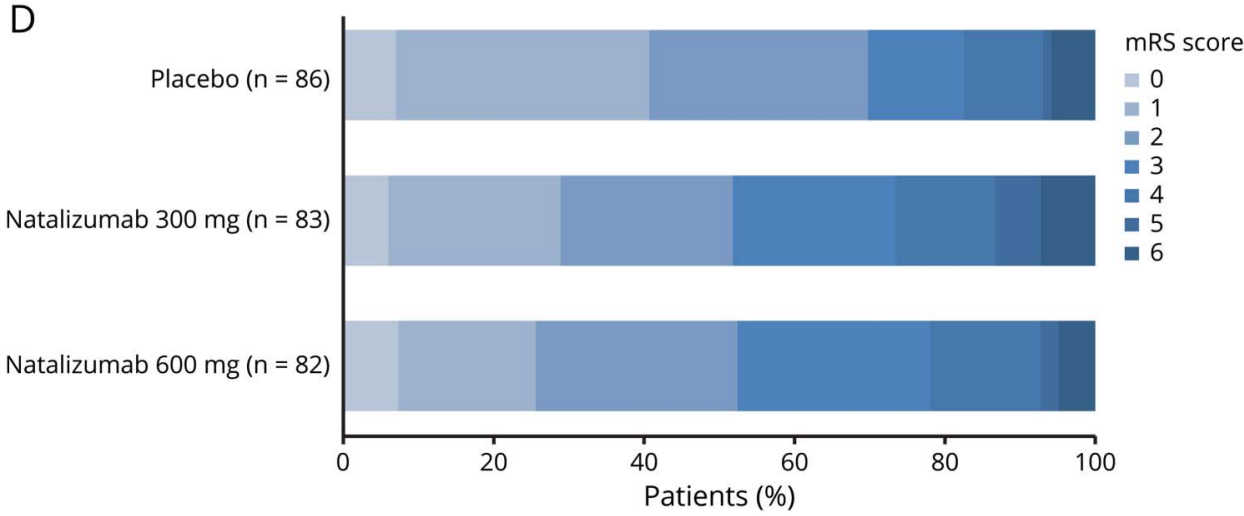

Subgroup analyses of the odds of an excellent outcome on (A) the composite endpoint, (B) the modified Rankin scale (mRS), and (C) the Barthel Index (BI) at day 90 in the modified intent-to-treat population treated with natalizumab $300 \mathrm{mg}$ or $600 \mathrm{mg}$ vs placebo and (D) distributions of mRS scores at day 90 . Cl = confidence interval; OR = odds ratio; tPA = tissue plasminogen activator. 

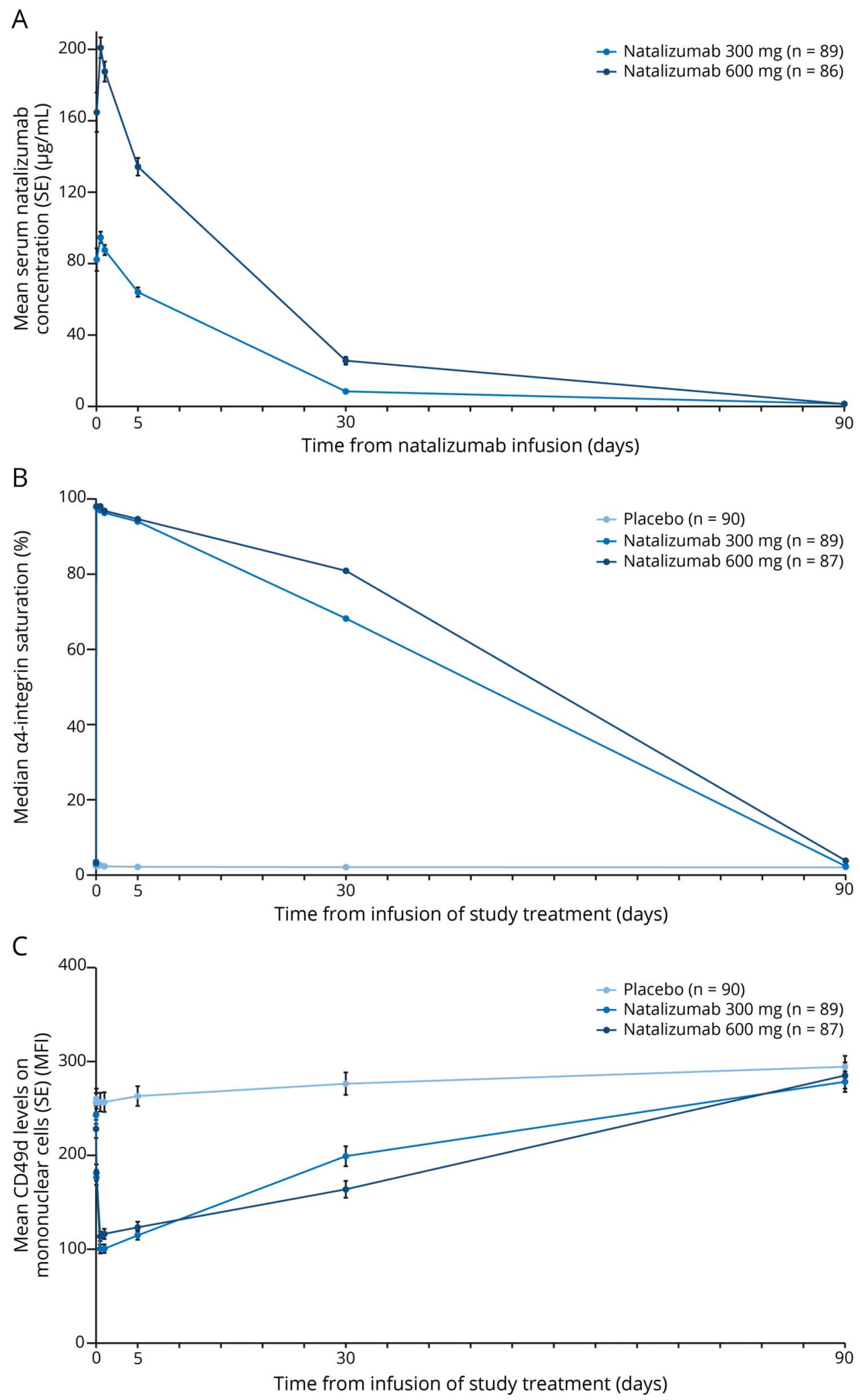

Pharmacokinetic and pharmacodynamic assessments of (A) serum natalizumab concentration (concentrations were below detectable levels in 1 natalizumab $600 \mathrm{mg}$ patient at 24 hours, 6 natalizumab $300 \mathrm{mg}$ patients and 4 natalizumab $600 \mathrm{mg}$ patients at 30 days, and 59 natalizumab 300 mg patients and 60 natalizumab $600 \mathrm{mg}$ patients at 90 days). (B) a4 integrin saturation (for a4 integrin saturation, median values were plotted over time instead of mean values due to outliers; 2 participants in the placebo group at 30 days and 1 participant in the placebo group at 90 days had extremely high a4 integrin saturation values due to laboratory errors), and (C) CD49d levels. Pharmacokinetic analyses were performed for 176 patients (87 in the natalizumab $300 \mathrm{mg}$ group and 89 in the natalizumab $600 \mathrm{mg}$ group) in the pharmacokinetic population, which included patients who had received the entire infusion of natalizumab at the baseline visit and had at least 1 measurable sample collected for the determination of natalizumab concentrations. The pharmacodynamic population included all patients who received the entire infusion of study treatment and had at least 1 postbaseline pharmacodynamic assessment (90 in the placebo group, 87 in the natalizumab $300 \mathrm{mg}$ group, and 89 in the natalizumab $600 \mathrm{mg}$ group). $\mathrm{MFI}=$ mean fluorescence intensity; SE = standard error.

$600 \mathrm{mg}$ group within 1 hour after natalizumab infusion (figure 3B). Median $\alpha 4$ integrin saturation remained high through 30 days postdose (ranging from $68.2 \%$ to $97.0 \%$ in the natalizumab $300 \mathrm{mg}$ group and from $80.9 \%$ to $98.1 \%$ in the natalizumab $600 \mathrm{mg}$ group) and decreased to approximately baseline levels by 90 days. Similar timing was observed for the 
Table 3 Exploratory efficacy endpoints at day 90 and single-dose pharmacokinetic parameters

\begin{tabular}{|c|c|c|c|c|c|c|}
\hline & \multicolumn{2}{|c|}{ Placebo } & \multicolumn{2}{|c|}{ Natalizumab 300 mg } & \multicolumn{2}{|c|}{ Natalizumab 600 mg } \\
\hline & $\mathbf{n}$ & $\begin{array}{l}\text { Mean } \\
\text { (SD) }\end{array}$ & $\mathbf{n}$ & $\begin{array}{l}\text { Mean (SD) or median (minimum, } \\
\text { maximum) }\end{array}$ & $\mathbf{n}$ & $\begin{array}{l}\text { Mean (SD) or median (minimum, } \\
\text { maximum) }\end{array}$ \\
\hline \multicolumn{7}{|l|}{ Exploratory efficacy outcome } \\
\hline FIM score & 78 & $\begin{array}{l}110.7 \\
(25.5)\end{array}$ & 73 & $105.3(29.0)$ & 72 & $106.6(24.2)$ \\
\hline $\begin{array}{l}\text { SDMT, number of correct } \\
\text { responses }\end{array}$ & 58 & $\begin{array}{l}41.4 \\
(36.1)\end{array}$ & 58 & $33.0(23.3)$ & 57 & $41.8(33.4)$ \\
\hline FSS score & 71 & $\begin{array}{l}30.5 \\
(16.4)\end{array}$ & 69 & $33.9(17.5)$ & 69 & $37.2(17.4)$ \\
\hline BDI-2 score & 74 & $7.4(6.7)$ & 70 & $10.8(10.3)$ & 69 & $9.4(8.8)$ \\
\hline $\begin{array}{l}\text { EQ-5D-3L, best imaginable } \\
\text { health state }\end{array}$ & 79 & $\begin{array}{l}69.2 \\
(20.3)\end{array}$ & 74 & $65.1(23.5)$ & 74 & $65.0(23.0)$ \\
\hline \multicolumn{7}{|l|}{ PK parameter } \\
\hline $\mathrm{C}_{\max }, \mathrm{mg} / \mathrm{L}$ & & & 88 & $103.0(55.6,474.0)$ & 86 & $224.0(105.0,622.0)$ \\
\hline$t_{\max }, h$ & & & 88 & $10.32(0.67,25.00)$ & 86 & $9.85(0.70,85.23)$ \\
\hline$A U C_{0-\infty}, h \times m g / L$ & & & 59 & $25,232.73(3,974.86,53,613.29)$ & 56 & $58,351.74(7,006.69,122,136.90)$ \\
\hline $\mathrm{AUC}_{0-120}, \mathrm{~h} \times \mathrm{mg} / \mathrm{L}$ & & & 73 & $8,773.07(3,022.81,14,266.41)$ & 70 & $18,643.83(6,930.66,31,431.55)$ \\
\hline $\mathrm{AUC}_{0-672}, \mathrm{~h} \times \mathrm{mg} / \mathrm{L}$ & & & 72 & $23,316.18(3,972.15,42,937.39)$ & 64 & $51,023.92(7,008.39,93,170.24)$ \\
\hline$A U C_{0-2160}, h \times m g / L$ & & & 59 & $25,224.41(3,974.44,53,255.35)$ & 56 & $58,161.77(7,007.20,120,214.30)$ \\
\hline$t_{\text {last, }}, h$ & & & 88 & $703.23(11.08,2090.13)$ & 86 & $668.97(19.10,2266.35)$ \\
\hline Vss, L & & & 59 & $3.36(2.02,7.56)$ & 56 & $3.21(2.07,7.61)$ \\
\hline Clearance, L/h & & & 59 & $0.013(0.006,0.075)$ & 56 & $0.010(0.005,0.086)$ \\
\hline Half-life, $h$ & & & 59 & $195.46(52.24,483.54)$ & 56 & $237.83(18.54,424.29)$ \\
\hline
\end{tabular}

Abbreviations: $\mathrm{AUC}=$ area under the serum concentration vs time curve from dosing; $\mathrm{BDI}-2=$ Beck Depression Inventory 2; EQ-5D-3L $=$ EuroQoL 5 dimensions/3 levels; $C_{\max }=$ peak concentration; FIM = Functional Independence Measure; FSS = Fatigue Severity Scale; PK = pharmacokinetics; SDMT = Symbol Digit Modalities Test; $t_{\text {last }}=$ time of last measurable concentration; $t_{\max }=$ time to $C_{\max }$ iss $=$ apparent volume of distribution, steady state .

The pharmacokinetics population includes patients who have received natalizumab at baseline and had at least 1 measurable sample collected for the determination of natalizumab.

change in CD49d expression, which decreased shortly after natalizumab dosing and returned to baseline levels by 90 days (figure 3C).

\section{Safety}

In the safety population (natalizumab $300 \mathrm{mg}, \mathrm{n}=90$; natalizumab $600 \mathrm{mg}, \mathrm{n}=89$; placebo, $\mathrm{n}=91$ ), the incidence of AEs was similar across treatment groups, with at least one $\mathrm{AE}$ reported in 81 patients (90.0\%) in the natalizumab $300 \mathrm{mg}$ group, 82 patients $(92.1 \%)$ in the natalizumab $600 \mathrm{mg}$ group, and 84 patients (92.3\%) in the placebo group. The incidence of moderate or severe AEs was higher in the natalizumab $600 \mathrm{mg}$ group (63 [70.8\%]) than the natalizumab $300 \mathrm{mg}(47$ [52.2\%]) or placebo (51 [56.0\%]) groups. Twenty-three patients $(25.6 \%)$ receiving natalizumab $300 \mathrm{mg}, 29$ patients (32.6\%) receiving natalizumab $600 \mathrm{mg}$, and 19 patients (20.9\%) receiving placebo reported an SAE. Table 4 shows the incidence of treatment-emergent AEs and SAEs in each group.
Overall, 15 patients died on or before day 90 (6 patients [6.7\%] in the natalizumab $300 \mathrm{mg}$ group, 4 patients [4.5\%] in the natalizumab $600 \mathrm{mg}$ group, and 5 patients [5.5\%] in the placebo group). One patient treated with natalizumab $300 \mathrm{mg}$ died of an SAE (respiratory failure) considered related to study treatment. Although the patient was of advanced age (80 years) and had medical history of diabetes, smoking, and hyperlipidemia, the role of natalizumab could not be excluded. No patients treated with placebo or natalizumab $600 \mathrm{mg}$ died of SAEs considered related to study treatment.

\section{Discussion}

In the ACTION II study, a single infusion of natalizumab at a dose of either 300 or $600 \mathrm{mg}$ was associated with a decreased likelihood of an excellent or good neurologic outcome. These results were consistent across several outcome measures, including the $\mathrm{mRS}$, the $\mathrm{BI}$, and other patient-centered functional outcome scales used 
Table 4 Incidence of treatment-emergent adverse events (TEAEs) and serious adverse events (SAES)

\begin{tabular}{|c|c|c|c|}
\hline MedDRA preferred term, $\mathrm{n}(\%)$ & Placebo $(n=91)$ & Natalizumab 300 mg $(n=90)$ & Natalizumab $600 \mathrm{mg}(\mathrm{n}=89)$ \\
\hline \multicolumn{4}{|c|}{ TEAEs occurring in $\geq 10 \%$ of patients in any treatment group } \\
\hline Constipation & $18(19.8)$ & $19(21.1)$ & $23(25.8)$ \\
\hline Headache & $15(16.5)$ & $16(17.8)$ & $20(22.5)$ \\
\hline Pyrexia & $11(12.1)$ & $19(21.1)$ & $14(15.7)$ \\
\hline Urinary tract infection & $11(12.1)$ & $14(15.6)$ & $16(18.0)$ \\
\hline Depression & $16(17.6)$ & $13(14.4)$ & $10(11.2)$ \\
\hline Insomnia & $4(4.4)$ & $11(12.2)$ & $10(11.2)$ \\
\hline Hypokalemia & $6(6.6)$ & $12(13.3)$ & $6(6.7)$ \\
\hline Pneumonia & $5(5.5)$ & $2(2.2)$ & $9(10.1)$ \\
\hline \multicolumn{4}{|c|}{ Treatment-emergent SAEs occurring in $>1$ patient in any treatment group } \\
\hline Cerebrovascular accident & $2(2.2)$ & 0 & $3(3.4)$ \\
\hline Ischemic stroke & 0 & $3(3.3)$ & $2(2.2)$ \\
\hline Cerebral hemorrhage & 0 & $3(3.3)$ & $1(1.1)$ \\
\hline Stroke in evolution & $1(1.1)$ & $2(2.2)$ & $1(1.1)$ \\
\hline Cerebral infarction & $1(1.1)$ & 0 & $2(2.2)$ \\
\hline Cerebral artery occlusion & 0 & 0 & $2(2.2)$ \\
\hline Pneumonia & $2(2.2)$ & 0 & $1(1.1)$ \\
\hline Sepsis & $2(2.2)$ & $1(1.1)$ & 0 \\
\hline Pulmonary embolism & 0 & $3(3.3)$ & $3(3.4)$ \\
\hline Pneumonia aspiration & $1(1.1)$ & $2(2.2)$ & $1(1.1)$ \\
\hline Respiratory failure & $1(1.1)$ & $1(1.1)$ & $2(2.2)$ \\
\hline Acute respiratory failure & $1(1.1)$ & 0 & $2(2.2)$ \\
\hline Cardiac arrest & $1(1.1)$ & $1(1.1)$ & $2(2.2)$ \\
\hline Hematuria & 0 & 0 & $2(2.2)$ \\
\hline
\end{tabular}

Abbreviation: MedDRA = Medical Dictionary for Regulatory Activities.

A patient was counted only once within each preferred term. Preferred terms are presented by decreasing incidence in the natalizumab $600 \mathrm{mg}$ column within each system organ class.

commonly in acute stroke studies. Combining the results of the ACTION and ACTION II trials did not provide any evidence of a benefit for natalizumab in AIS. The AE profiles of natalizumab $300 \mathrm{mg}$ and natalizumab $600 \mathrm{mg}$ were similar to that of placebo. The majority of AEs appeared to be due to the concurrent condition. Furthermore, the safety profile of natalizumab in ACTION II was consistent with that seen in the ACTION study ${ }^{15}$ and with the established safety profile of natalizumab. ${ }^{11}$ No new safety concerns were identified in this study.

ACTION II was conducted to explore the potential beneficial effects on clinical outcomes observed in the ACTION study. Although the primary endpoint of reduced MRIdefined infarct growth was not achieved in ACTION, treatment with natalizumab resulted in improvement on prespecified secondary and tertiary endpoints as measured by mRS, BI, SIS-16, and MoCA scores. The clinical benefits seen in ACTION were compatible with other preclinical research demonstrating that blocking a4 integrin reduced brain infiltration of leukocytes, attenuated expression of cytokines such as interferon- $\gamma$ and interleukin- 6 in brain tissue, and improved behavior. ${ }^{4,6,14}$ However, the overall findings of ACTION and ACTION II indicate that natalizumab most likely has a null effect in treating AIS.

Several factors may explain the different results observed in ACTION and ACTION II. First, the placebo group in ACTION II demonstrated a high rate of favorable outcomes. For instance, the proportion of placebo patients with an excellent score was substantially higher in ACTION II than in ACTION for both the mRS ( $41 \%$ vs $21 \%$ ) and the BI ( $67 \%$ vs $33 \%$ ). 
Response rates in the ACTION II placebo group were also higher than those observed in comparable AIS studies. ${ }^{22-24}$ These high rates of excellent outcomes in placebo-treated patients may have limited the ability to detect any benefit of natalizumab. While ACTION II included more patients who underwent thrombectomy than ACTION (42\% vs $7 \%$ ) and enrolled a subgroup with a longer time to treatment (9-24 hours), both of these variables were balanced across treatment arms. Thus, there was no evidence that these factors explained the discrepant results between ACTION and ACTION II. The efficacy findings in ACTION II were internally consistent across treatment arms, key subgroups, and endpoints, indicating that the findings in ACTION II were unlikely to be due to the inclusion of a single patient subpopulation or a random error on any one of the efficacy endpoints.

The results of the analysis of the combined data from ACTION and ACTION II are consistent with negative results from other trials in patients with AIS that have targeted other aspects of immune mechanisms and the detrimental effects of inflammation after stroke. For example, in a trial of 625 patients with AIS randomized to placebo or enlimomab, a murine intercellular adhesion molecule- 1 antibody that reduced leukocyte adhesion and infarct size in experimental stroke studies, 90-day outcomes were significantly worse among patients treated with enlimomab. ${ }^{25}$ Significantly more AEs (primarily infections and fever) were observed with enlimomab than with placebo. One of the limitations of enlimomab, however, was that as a murine antibody, it may have provoked an adverse immune reaction. ${ }^{26}$ Subsequent testing of a humanized monoclonal antibody targeted against neutrophil $\beta 2$ integrin $\mathrm{CD} 18$ (Hu23F2G) in a phase 3 trial was stopped early for futility. ${ }^{27}$ Trials of other immunomodulatory drugs, such as minocycline, have been similarly negative; studies of other agents are ongoing. ${ }^{27}$

The primary limitation of this double-blind, placebocontrolled, randomized study was its sample size. While the sample size was estimated in order to strengthen or weaken confidence in the findings of the ACTION trial, the achieved sample size was relatively low to evaluate treatment effects on clinical outcomes, and an imbalance of unmeasured confounders across treatment groups is possible. This limitation is partially mitigated by the preplanned combined analysis with the ACTION data, which likely provides the best overall estimate of treatment effect with natalizumab in AIS. ACTION II tested a limited number of treatment windows and doses and did not follow patients for longer than 90 days. However, there is some evidence from animal models that immune mechanisms may contribute to delayed, longterm cognitive outcomes after experimental ischemic stroke and that blocking these immune mechanisms can improve these cognitive outcomes. ${ }^{28}$

While the combined results of ACTION and ACTION II do not support a clinical benefit for natalizumab, the studies provide a robust assessment of targeting the VLA-4 pathway in AIS. The results of the trials offer valuable data to further direct the study of immune mechanisms in stroke. It remains possible that direct modulation of the CNS resident immune response or therapies directed to other peripheral immune cells such as neutrophils (which may not express significant levels of VLA-4) could achieve better outcomes for patients. In addition, a different temporal sequence of antagonism of peripheral immune cell infiltration may be required, particularly as immune mechanisms may also provide benefits for stroke recovery. ${ }^{29-31}$

The current findings provide strong evidence that prolonged saturation of the VLA-4 pathway, which mediates peripheral immune cell infiltration into the brain both in animal models of stroke and in other human diseases, does not improve outcomes in human stroke.

\section{Acknowledgment}

Alison Adams, $\mathrm{PhD}$ (Ashfield Healthcare Communications, Middletown, CT) provided medical writing support based on input from authors, and Joshua Safran (Ashfield Healthcare Communications) copyedited and styled the manuscript per journal requirements. Biogen reviewed and provided feedback on the manuscript to the authors.

\section{Study funding}

Biogen initiated and provided funding for this study and drafted and provided medical writing and editorial support in the development of this manuscript. Biogen was also involved in study design and collection, analysis, and interpretation of data, and Biogen reviewed and provided feedback on the manuscript. The authors, who include both Biogen employees and academic investigators, had full editorial control of this manuscript and provided final approval of all content. The corresponding author had full access to all data from the study and had final responsibility for the decision to submit the manuscript for publication.

\section{Disclosure}

M. Elkind's institution has received compensation for his providing consulting services for Biogen. Dr. Elkind has received personal compensation from Biotelemetry (Cardionet), BMS-Pfizer Partnership, Boehringer Ingelheim, and the Sanofi-Regeneron Partnership; has received royalties from UpToDate for chapters related to stroke; and has received personal compensation from the American Academy of Neurology for serving as an associate editor of Neurology ${ }^{\circledR}$. R. Veltkamp has received consulting fees, speaker honoraria, or both from Bayer, Biogen, Boehringer Ingelheim, BristolMyers Squibb, Daiichi Sankyo, Medtronic, Morphosys, and Pfizer; has received research support from Bayer, Boehringer Ingelheim, Bristol-Myers Squibb, Daiichi Sankyo, and Pfizer; and is an investigator of the Imperial BRC and the coordinating investigator of the PRESTIGE-AF consortium funded by the HORIZON2020 scheme. J. Montaner has 
received personal compensation from Biogen for serving as a trial coordinator and from Elsevier for serving as editor of Translational Proteomics. S. Claiborne Johnston has received research support from AstraZeneca. A. Singhal has received personal compensation for serving as a consultant from Omniox; professional fees for serving as a medical expert witness in medico-legal cases; honoraria from the American Academy of Neurology, Medlink, and UpToDate; and research support from Boehringer Ingelheim. A. Singhal's spouse was an employee of Biogen. A. Singhal's financial interests were reviewed and managed by Massachusetts General Hospital and Partners Healthcare in accordance with their conflict of interest policies. K. Becker has received personal compensation from ICON plc for serving on outcome adjudication committees for clinical trials and from Biogen for serving on an external advisory board. M. Lansberg has received personal compensation from Biogen for serving on an advisory board. W. Tang was an employee of Biogen at the time of these analyses and may hold stock in Biogen. R. Kasliwal was an employee of Biogen at the time of these analyses and may hold stock in Biogen. J. Elkins was an employee of Biogen at the time of these analyses and holds stock in Biogen. Go to Neurology.org/N for full disclosures.

\section{Publication history}

Received by Neurology May 24, 2019. Accepted in final form February 14, 2020.

Appendix 1 Authors

\begin{tabular}{|c|c|c|}
\hline Name & Location & Contribution \\
\hline $\begin{array}{l}\text { Mitchell S.V. } \\
\text { Elkind, MD }\end{array}$ & $\begin{array}{l}\text { Columbia University, New } \\
\text { York, NY }\end{array}$ & $\begin{array}{l}\text { Contributed to study } \\
\text { design, data } \\
\text { interpretation, and } \\
\text { reviewed and approved } \\
\text { the final manuscript; } \\
\text { administered study; } \\
\text { wrote first draft; } \\
\text { contributed to data } \\
\text { collection }\end{array}$ \\
\hline
\end{tabular}

\begin{tabular}{ll}
\hline Roland & Imperial College London, UK; \\
Veltkamp, & Alfried-Krupp Krankenhaus, \\
MD & Essen, Germany
\end{tabular}

Contributed to study design, data interpretation, and reviewed and approved the final manuscript; contributed to data collection

\begin{tabular}{|c|c|c|}
\hline $\begin{array}{l}\text { Joan } \\
\text { Montaner, } \\
\text { MD, PhD }\end{array}$ & $\begin{array}{l}\text { Vall d'Hebron Research } \\
\text { Institute (VHIR), Barcelona; } \\
\text { Institute of Biomedicine of } \\
\text { Seville (IBiS) Stroke } \\
\text { Programme, Seville, Spain }\end{array}$ & $\begin{array}{l}\text { Contributed to study } \\
\text { design, data } \\
\text { interpretation, and } \\
\text { reviewed and approved } \\
\text { the final manuscript; } \\
\text { contributed to data } \\
\text { collection }\end{array}$ \\
\hline $\begin{array}{l}\text { S. Claiborne } \\
\text { Johnston, } \\
\text { MD, PhD }\end{array}$ & University of Texas, Austin & $\begin{array}{l}\text { Contributed to study } \\
\text { design, data } \\
\text { interpretation, and } \\
\text { reviewed and approved } \\
\text { the final manuscript; } \\
\text { contributed to data } \\
\text { collection }\end{array}$ \\
\hline
\end{tabular}

Appendix 1 (continued)

\begin{tabular}{|c|c|c|}
\hline Name & Location & Contribution \\
\hline $\begin{array}{l}\text { Aneesh B. } \\
\text { Singhal, MD }\end{array}$ & $\begin{array}{l}\text { Massachusetts General } \\
\text { Hospital, Boston }\end{array}$ & $\begin{array}{l}\text { Contributed to study } \\
\text { design, data } \\
\text { interpretation, and } \\
\text { reviewed and approved } \\
\text { the final manuscript; } \\
\text { contributed to data } \\
\text { collection }\end{array}$ \\
\hline $\begin{array}{l}\text { Kyra } \\
\text { Becker, MD }\end{array}$ & $\begin{array}{l}\text { University of Washington, } \\
\text { Seattle }\end{array}$ & $\begin{array}{l}\text { Contributed to study } \\
\text { design, data } \\
\text { interpretation, and } \\
\text { reviewed and approved } \\
\text { the final manuscript }\end{array}$ \\
\hline $\begin{array}{l}\text { Maarten G. } \\
\text { Lansberg, } \\
\text { MD, PhD }\end{array}$ & $\begin{array}{l}\text { Stanford University Medical } \\
\text { Center, Stanford Stroke } \\
\text { Center, CA }\end{array}$ & $\begin{array}{l}\text { Contributed to study } \\
\text { design, data } \\
\text { interpretation, and } \\
\text { reviewed and approved } \\
\text { the final manuscript; } \\
\text { contributed to data } \\
\text { collection }\end{array}$ \\
\hline $\begin{array}{l}\text { Weihua } \\
\text { Tang, PhD }\end{array}$ & $\begin{array}{l}\text { Biogen, Cambridge, MA, at } \\
\text { the time of this analysis }\end{array}$ & $\begin{array}{l}\text { Contributed to study } \\
\text { design, data } \\
\text { interpretation, and } \\
\text { reviewed and approved } \\
\text { the final manuscript; } \\
\text { conducted data analysis }\end{array}$ \\
\hline $\begin{array}{l}\text { Rachna } \\
\text { Kasliwal, } \\
\text { MPH }\end{array}$ & $\begin{array}{l}\text { Biogen, Cambridge, MA, at } \\
\text { the time of this analysis }\end{array}$ & $\begin{array}{l}\text { Contributed to study } \\
\text { design, data } \\
\text { interpretation, and } \\
\text { reviewed and approved } \\
\text { the final manuscript }\end{array}$ \\
\hline $\begin{array}{l}\text { Jacob Elkins, } \\
\text { MD }\end{array}$ & $\begin{array}{l}\text { Biogen, Cambridge, MA, at } \\
\text { the time of this analysis }\end{array}$ & $\begin{array}{l}\text { Contributed to study } \\
\text { design, data } \\
\text { interpretation, and } \\
\text { reviewed and approved } \\
\text { the final manuscript; } \\
\text { administered study }\end{array}$ \\
\hline
\end{tabular}

Appendix 2 ACTION II Investigators Group

Germany: Joerg Berrouschot, Thomas Els, Dominik Michalski, Sebastian Jander, Bernd Kallmuenzer, Patrick Oschmann, Christian Foerch, Matthias Maschke, Christian Nolte, Hassan Soda, Timolaos Rizos, Peter Schellinger, Katharina Althaus, Frederick Palm, Sebastian Schellong, Sven Poli, Goetz Thomalla, Achim Gass, Jessica Barlinn, Jens Minnerup, Peter Rieckmann. Spain: Miguel Alberte Woodward, Maria del Mar Castellanos Rodrigo, Victoria Eugenia Fernandez Sanchez, Antonio Gil Nuñez, Jaime Masjuan Vallejo, Carlos Molina Cateriano, Mikel Terceño Izaga, Tomas Segura Martin, Francisco Moniche Alvarez, Juan Francisco Arenillas Lara, Jaime Roquer Gonzalez, Meritxell Gomis Cortina, Alain Luna Rodriguez, Miguel Angel Gamero, Alvaro Ximenez-Carrillo Rico. United Kingdom: David Cohen, Bhavini Patel, Roland Veltkamp, Sreeman Andole, Indira Natarajan, David Werring. United States: Irfan Altafullah, Fen Lei Chang, Kyra Becker, Mitchell Elkind, Wayne Clark, Brett Cucchiara, Christine Holmstedt, Joseph Hanna,

Thomas Hemmen, Biggya Sapkota, Qaisar Shah, John Terry, Diana GreeneChandos, Brian Wiseman, Jin-Moo Lee, Ted Lowenkopf, Jodi Dodds, Lucian Maidan, Sidney Starkman, Patricia Musolino, James Gebel, Douglas Mayson, Yunxia Wang, James Frey, Christina Wilson.

\section{References}

1. Chamorro A, Meisel A, Planas AM, Urra X, van de Beek D, Veltkamp R. The immunology of acute stroke. Nat Rev Neurol 2012;8:401-410.

2. Hurn PD, Subramanian S, Parker SM, et al. T- and B-cell-deficient mice with experimental stroke have reduced lesion size and inflammation. J Cereb Blood Flow Metab 2007;27:1798-1805.

3. Yilmaz G, Arumugam TV, Stokes KY, Granger DN. Role of T lymphocytes and interferon-gamma in ischemic stroke. Circulation 2006;113:2105-2112. 
4. Becker K, Kindrick D, Relton J, Harlan J, Winn R. Antibody to the alpha4 integrin decreases infarct size in transient focal cerebral ischemia in rats. Stroke 2001;32: 206-211.

5. Langhauser F, Kraft P, Gob E, et al. Blocking of alpha4 integrin does not protect from acute ischemic stroke in mice. Stroke 2014;45:1799-1806.

6. Liesz A, Zhou W, Mracsko E, et al. Inhibition of lymphocyte trafficking shields the brain against deleterious neuroinflammation after stroke. Brain 2011;134: 704-720.

7. Neumann J, Riek-Burchardt M, Herz J, et al. Very-late-antigen-4 (VLA-4)-mediated brain invasion by neutrophils leads to interactions with microglia, increased ischemic injury and impaired behavior in experimental stroke. Acta Neuropathol 2015;129: 259-277.

8. Llovera G, Hofmann K, Roth S, et al. Results of a preclinical randomized controlled multicenter trial (pRCT): anti-CD49d treatment for acute brain ischemia. Sci Transl Med 2015;7:299ra121.

9. Rudick RA, Sandrock A. Natalizumab: $\alpha 4$-integrin antagonist selective adhesion molecule inhibitors for MS. Expert Rev Neurother 2004;4:571-580.

10. Polman CH, O'Connor PW, Havrdova E, et al. A randomized, placebo-controlled trial of natalizumab for relapsing multiple sclerosis. N Engl J Med 2006;354:899-910.

11. Tysabri (natalizumab) [prescribing information]. Cambridge, MA: Biogen; 2018

12. Miller DH, Khan OA, Sheremata WA, et al. A controlled trial of natalizumab for relapsing multiple sclerosis. N Engl J Med 2003;348:15-23.

13. Kirveskari J, Bono P, Granfors K, Leirisalo-Repo M, Jalkanen S, Salmi M. Expression of alpha4-integrins on human neutrophils. J Leukoc Biol 2000;68:243-250.

14. Relton JK, Sloan KE, Frew EM, Whalley ET, Adams SP, Lobb RR. Inhibition of alpha 4 integrin protects against transient focal cerebral ischemia in normotensive and hypertensive rats. Stroke 2001;32:199-205.

15. Elkins J, Veltkamp R, Montaner J, et al. Safety and efficacy of natalizumab in patients with acute ischaemic stroke (ACTION): a randomised, placebo-controlled, doubleblind phase 2 trial. Lancet Neurol 2017;16:217-226.

16. Lyden P, Lu M, Jackson C, et al. Underlying structure of the National Institutes of Health Stroke Scale: results of a factor analysis. NINDS tPA Stroke Trial Investigators. Stroke 1999;30:2347-2354.

17. Sulter G, Steen C, De Keyser J. Use of the Barthel index and modified Rankin scale in acute stroke trials. Stroke 1999;30:1538-1541.
18. National Institute of Neurological Disorders and Stroke rt-PA Stroke Study Group. Tissue plasminogen activator for acute ischemic stroke. N Engl J Med 1995;333. $1581-1587$.

19. Duncan PW, Lai SM, Bode RK, Perera S, DeRosa J. Stroke Impact Scale-16: a brief assessment of physical function. Neurology 2003;60:291-296.

20. Chiti G, Pantoni L. Use of Montreal Cognitive Assessment in patients with stroke. Stroke 2014;45:3135-3140.

21. Hacke W, Kaste M, Bluhmki E, et al. Thrombolysis with alteplase 3 to 4.5 hours after acute ischemic stroke. N Engl J Med 2008;359:1317-1329.

22. Shuaib A, Lees KR, Lyden P, et al. NXY-059 for the treatment of acute ischemic stroke. N Engl J Med 2007;357:562-571.

23. Albers GW, von Kummer R, Truelsen T, et al. Safety and efficacy of desmoteplase given 3-9 $\mathrm{h}$ after ischaemic stroke in patients with occlusion or high-grade stenosis in major cerebral arteries (DIAS-3): a double-blind, randomised, placebo-controlled phase 3 trial. Lancet Neurol 2015;14:575-584.

24. Lees KR, Zivin JA, Ashwood T, et al. NXY-059 for acute ischemic stroke. N Engl J Med 2006;354:588-600.

25. Enlimomab Acute Stroke Trial Investigators. Use of anti-ICAM-1 therapy in ischemic stroke: results of the Enlimomab Acute Stroke Trial. Neurology 2001;57:1428-1434.

26. Furuya K, Takeda H, Azhar S, et al. Examination of several potential mechanisms for the negative outcome in a clinical stroke trial of enlimomab, a murine anti-human intercellular adhesion molecule-1 antibody: a bedside-to-bench study. Stroke 2001, 32:2665-2674.

27. Veltkamp R, Gill D. Clinical trials of immunomodulation in ischemic stroke. Neurotherapeutics 2016;13:791-800.

28. Doyle KP, Quach LN, Sole M, et al. B-lymphocyte-mediated delayed cognitive im pairment following stroke. J Neurosci 2015;35:2133-2145.

29. Gill D, Veltkamp R. Dynamics of T cell responses after stroke. Curr Opin Pharmaco 2016;26:26-32.

30. Liu Z, Chopp M. Astrocytes, therapeutic targets for neuroprotection and neurorestoration in ischemic stroke. Prog Neurobiol 2016;144:103-120.

31. Amantea D, Greco R, Micieli G, Bagetta G. Paradigm shift to neuroimmunomodulation for translational neuroprotection in stroke. Front Neurosci 2018, $12: 241$ 


\section{Neurology}

\section{Natalizumab in acute ischemic stroke (ACTION II): A randomized, placebo-controlled trial}

Mitchell S.V. Elkind, Roland Veltkamp, Joan Montaner, et al.

Neurology 2020;95;e1091-e1104 Published Online before print June 26, 2020

DOI 10.1212/WNL.0000000000010038

This information is current as of June 26, 2020 Updated Information \&
Services

References

Subspecialty Collections

Permissions \& Licensing

Reprints including high resolution figures, can be found at: http://n.neurology.org/content/95/8/e1091.full

This article cites 30 articles, 12 of which you can access for free at: http://n.neurology.org/content/95/8/e1091.full\#ref-list-1

This article, along with others on similar topics, appears in the following collection(s):

All CBMRT/Null Hypothesis

http://n.neurology.org/cgi/collection/all_cbmrt_null_hypothesis All Cerebrovascular disease/Stroke http://n.neurology.org/cgi/collection/all_cerebrovascular_disease_strok e

All Clinical Neurology

http://n.neurology.org/cgi/collection/all_clinical_neurology Class I

http://n.neurology.org/cgi/collection/class_1

Information about reproducing this article in parts (figures,tables) or in its entirety can be found online at:

http://www.neurology.org/about/about_the_journal\#permissions

Information about ordering reprints can be found online:

http://n.neurology.org/subscribers/advertise

Neurology ${ }^{\circledR}$ is the official journal of the American Academy of Neurology. Published continuously since 1951, it is now a weekly with 48 issues per year. Copyright Copyright ( 2020 The Author(s). Published by Wolters Kluwer Health, Inc. on behalf of the American Academy of Neurology.. All rights reserved. Print ISSN: 0028-3878. Online ISSN: 1526-632X.

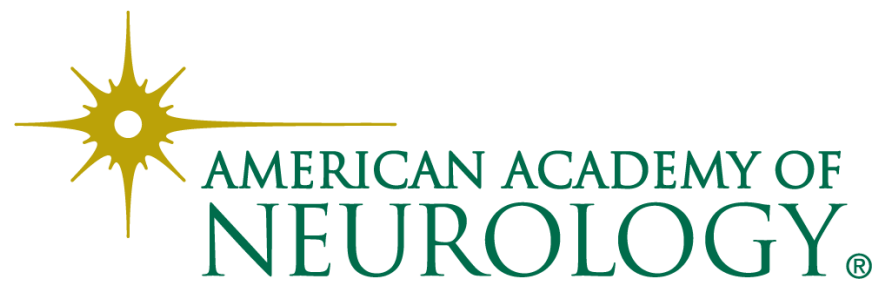

